\title{
Legionnaires' disease: a review of 79 community acquired cases in Nottingham
}

\author{
M A WOODHEAD, J T MACFARLANE \\ From the Department of Thoracic Medicine, City Hospital, Nottingham
}

\begin{abstract}
Seventy nine cases of sporadic, community acquired legionnaires' disease have been reviewed. Annual and seasonal variation in incidence was noted. The mean age of the patients was 53 years and $50(63 \%)$ were male. Pre-existing chronic diseases were present in only $23(29 \%)$, including two patients receiving immunosuppressive treatment. Common symptoms included unproductive cough, dyspnoea, chest pain, headache, confusion, nausea, vomiting, and diarrhoea. Respiratory symptoms were absent, however, in $17(22 \%)$. Localising chest signs were present in $74(95 \%)$ cases. Frequent laboratory findings included lymphopenia, high erythrocyte sedimentation rate, hyponatraemia, raised urea and creatinine concentrations, abnormal liver function, hypophosphataemia, hypoalbuminaemia, proteinuria, and haematuria. Thirteen patients died $(16 \%)$, including nine of 20 who received assisted ventilation. The mortality rate in patients treated with erythromycin (11\%) was lower than in those who received other antibiotics $(23 \%)$, but this difference was not statistically significant. Of the features noted on admission, only a high plasma urea concentration was significantly associated with death. Sporadic community acquired legionnaires' disease is a not uncommon disorder, which with appropriate treatment has a prognosis similar to that of other forms of community acquired pneumonia.
\end{abstract}

The discovery of legionnaires' disease in Philadelphia in $1976^{1}$ was followed by several reports of the disease in Britain in both the medical and the popular press. It soon became apparent that legionnaires' disease was not a "new" disease, the first known case in the United States being diagnosed retrospectively in $1947^{2}$ and the first in Britain in $1972 .^{3}$ Subsequently it has been recognised that legionnaires' disease is not uncommon and may account for a considerable proportion of all sporadic cases of pneumonia in the United States, ${ }^{4}$ Britain, ${ }^{56}$ and Europe. ${ }^{7-11}$ Although sporadic community acquired pneumonia is probably the most common form of legionnaires' disease, ${ }^{12}$ reported experience has largely concerned epidemic and nosocomial infections. ${ }^{1314}$ This paucity of information about community acquired legionnaires' disease has prompted us to review our experience in Nottingham.

Address for reprint requests: Dr M A Woodhead, Department of Thoracic Medicine, City Hospital, Nottingham NG5 IPB.

Accepted 3 January 1986

\section{Methods}

Cases of legionnaires' disease occurring in Nottingham from 1972 to 1984 were identified from the records of the department of Microbiology and Public Health Laboratory Service which serves the two district general hospitals in the city. The diagnosis of legionella pneumonia was accepted for any patient with a fourfold or greater rise in indirect immunofluorescent antibody titre or a single titre of $\geqslant 256$, formolised yolk sac legionella antigens being used $^{15}$ or if the legionella organism was cultured either during life or from post mortem tissues or the bacterium was demonstrated by direct immunofluorescent stains in body fluids or postmortem lung tissue. Any patient becoming ill while a hospital inpatient or within two weeks of discharge from hospital was presumed to have acquired a nosocomial infection and was excluded. Information on all patients was extracted retrospectively from the case notes. The radiological features have been described elsewhere. ${ }^{16}$

Statistical analysis was performed using the $\chi^{2}$ test. 


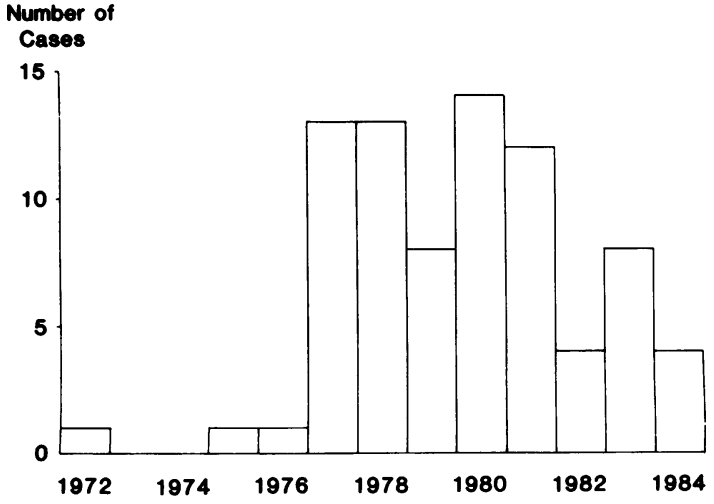

Annual incidence of community acquired legionnaires' disease in Nottingham.

\section{Results}

Ninety confirmed cases of legionnaires' disease were identified during the 12 years. Four were nosocomial; case notes could not be found for five; and two patients were not admitted to hospital. Thus 79 community acquired cases form the basis for this study.

The annual incidence varied widely, most cases occurring during 1977-81 (figure). A seasonal variation was noted with $57(72 \%)$ cases occurring in the months July to December.

The mean age of the patients was 53 (range 25-83) years and $50(63 \%)$ were male. Seven patients had recently returned from abroad; one of them had been taken ill at the Rio Park Hotel in Benidorm, Spain. Five patients had been recently discharged from hospital, but in each case this was more than one month before the onset of legionnaires' disease. An addi-
Table 1 Pre-existing chronic diseases (29 diseases in 23 patients) among 79 cases of community acquired legionnaires' disease

\begin{tabular}{ll}
\hline & No \\
\hline Cardiac disease & 8 \\
Respiratory diseases & 6 \\
Diabetes mellitus & 3 \\
Renal disease & 2 \\
Cancer & 0 \\
Immunosuppressive treatment & 2 \\
Others & 8
\end{tabular}

tional six patients were known to have had recent hospital contact; four of these were currently employed in hospital.

Of 70 patients whose smoking history was known, G $54(77 \%)$ were current smokers or had recently 을 stopped smoking and 33 of the $42(79 \%)$ whose con- sumption was known smoked 20 or more cigarettes a day. Of 53 patients whose alcohol history was available, $40(75 \%)$ took regular alcohol; of the 22 whose precise consumption was known nine $(41 \%)$ regularly $\vec{\bullet}$ drank more than 50 units a week (one unit = one half $\stackrel{\circ}{\circ}$ pint of beer or one measure of spirit).

Twenty three $(29 \%)$ patients had pre-existing chronic diseases and $32(41 \%)$ were having regular drug treatment (table 1). Chronic cardiovascular and respiratory diseases occurred most frequently. There were no patients with cancer and only two patients were having immunosuppressive treatment - one was taking prednisolone for sarcoidosis, having previously had a splenectomy, and the other, who had systemic lupus erythematosus, was taking prednisolone and cyclophosphamide.

CLINICAL FEATURES

The mean duration of symptoms before admission to

Table 2 Frequency of symptoms (\%) for patients with community acquired legionella pneumonia compared with previous reported experience

\begin{tabular}{|c|c|c|c|c|}
\hline Symptom & $\begin{array}{l}\text { Nottingham } \\
(\text { present study) } \\
(n=78)^{*}\end{array}$ & $\begin{array}{l}\text { Community } \\
\text { acquired }(U S A) \\
(n=67)\end{array}$ & $\begin{array}{l}\text { Epidemic } \\
(U S A) \\
(n=123)\end{array}$ & $\begin{array}{l}\text { Epidemic }^{14} \\
(\text { Sweden }) \\
(n=68)\end{array}$ \\
\hline $\begin{array}{l}\text { Respiratory } \\
\text { Cough } \\
\text { Expectoration } \\
\text { Haemoptysis } \\
\text { Dyspnoea } \\
\text { Chest pain } \\
\text { Upper respiratory tract infection }\end{array}$ & $\begin{array}{l}78 \\
73 \\
41 \\
14 \\
35 \\
36 \\
14\end{array}$ & $\begin{array}{l}\overline{72} \\
45 \\
18 \\
37 \\
18 \\
10\end{array}$ & $\begin{array}{l}\overline{86} \\
50 \\
\overline{59} \\
52 \\
-\end{array}$ & $\begin{array}{r}76 \\
65 \\
0 \\
34 \\
28 \\
0\end{array}$ \\
\hline $\begin{array}{l}\text { Neurological } \\
\text { Headache } \\
\text { Confusion }\end{array}$ & $\begin{array}{l}54 \\
27 \\
35\end{array}$ & $\begin{array}{l}33 \\
34 \\
53\end{array}$ & $\begin{array}{l}-53 \\
21\end{array}$ & $\begin{array}{l}44 \\
56 \\
32\end{array}$ \\
\hline $\begin{array}{l}\text { Gastrointestinal } \\
\text { Nausea/Vomiting } \\
\text { Diarrhoea } \\
\text { Abdominal pain }\end{array}$ & $\begin{array}{r}40 \\
32 \\
22 \\
5\end{array}$ & $\begin{array}{r}-37 \\
27 \\
6\end{array}$ & $\begin{array}{l}\overline{23} \\
41 \\
-\end{array}$ & $\begin{array}{r}57 \\
34 \\
26 \\
9\end{array}$ \\
\hline
\end{tabular}

*Presenting symptoms not recorded in one patient. 
hospital (73 cases) was seven (range 1-24) days and $66(90 \%)$ patients had been admitted to hospital by seven days. Symptoms were recorded for all but one patient, who was moribund on admission (table 2). Although a non-productive cough was common, respiratory symptoms were absent in $17(22 \%)$ of cases. Neurological symptoms, found in $42(54 \%)$ cases, included not only headache in $21(27 \%)$ and confusion in $27(35 \%)$ but also dysarthria (four cases), gait disorder (five), diplopia (one), vertigo (one), and deafness of acute onset (one). Other symptoms noted on admission included rigors (11 cases), myalgia (five), rash (one). palpitations (one), and melaena (one).

Fever was the commonest abnormality found on initial examination, 51 of $71(72 \%)$ patients having an oral temperature of $39^{\circ} \mathrm{C}$ or more and $17(24 \%)$ of $40^{\circ} \mathrm{C}$ or more and only seven $(10 \%)$ having a temperature below $37.5^{\circ} \mathrm{C}$. Confusion was noted on examination in 32 of 74 cases $(43 \%)$ and a depressed conscious level in 15 of $60(25 \%)$. Tachycardia (pulse rate $\geqslant 100$ beats/min) occurred in 56 of 73 cases $(77 \%)$, with relative bradycardia (pulse rate $<100$ beats $/ \mathrm{min}$ in the presence of temperatures of $\geqslant 39.4^{\circ} \mathrm{C}$ ) noted in only $13(18 \%)$ patients, three of whom were taking negatively chronotropic drugs. Hypotension (systolic blood pressure $<100 \mathrm{~mm} \mathrm{Hg}$ ) on admission to hospital was noted in four patients. All patients were tachypnoeic (respiratory rate $\geqslant 20$ /minute in the 26 cases in which it was recorded). Localising chest signs were present in 72 of $76(95 \%)$ cases. These included crepitations in $65(86 \%)$ and dullness to percussion in $39(51 \%)$. Bronchial breathing was present in only $17(22 \%)$ and a pleural friction rub in six $(8 \%)$. Herpes labialis was noted in three patients.

\section{LABORATORY RESULTS}

Common laboratory findings are shown in table 3 . Creatine phosphokinase activity was increased in 11 of the 18 patients in whom it was measured, the highest activity being $1521 \mathrm{IU} / 1$.

\section{MICROBIOLOGY}

The diagnosis was based on a fourfold rise in immunofluorescent antibody titre in 67 patients and a single titre of 256 or more in three. Of those showing a fourfold rise, $26(39 \%)$ had an initial titre of 16 or more. Ten of these samples were taken at least five days after admission. Legionella pneumophila was cultured from only five patients-from sputum in one, from tracheal aspirates in three, and from bronchoscopic aspirates in one. The organism was demonstrated by immunofluorescent staining in postmortem lung tissue in eight cases. In $72(91 \%) L$ pneumophila of serogroup 1 was responsible. There were only two serogroup 5 infections and one serogroup 4, and one each of $L$ micdadei, $L$ gormanii, $L$ bozemanii, and $L$ dumoffii.

Evidence of dual infection was found in eight patients. Haemophilus influenzae was grown from the sputum of one patient on admission to hospital and in another a fourfold rise in Mycoplasma pneumoniae antibody titre was detected. Pneumococcal antigen was detected in specimens from six patients by countercurrent immunoelectrophoresis, ${ }^{17}$ from sputum in five and-urine in two cases.

Table 3 Laboratory findings on admission to hospital

\begin{tabular}{|c|c|}
\hline Feature & $\begin{array}{l}\text { Proportion of cases showing feature } \\
(\%)\end{array}$ \\
\hline $\begin{array}{l}\text { Leucocyte count } \geqslant 10 \times 10^{9} / 1 \\
\qquad 15 \times 10^{9} / 1 \\
\text { Lymphocyte count }<1.0 \times 10^{9} / 1 \\
\text { Erythrocyte sedimentation rate } \geqslant 50 \mathrm{~mm} \text { in } 1 \mathrm{~h} \\
\text { Platelets }<100 \times 10^{9} / 1\end{array}$ & $\begin{array}{r}46 / 73(63) \\
11 / 73(15) \\
34 / 61(56) \\
54 / 60(90) \\
26 / 60(43) \\
4 / 64(6)\end{array}$ \\
\hline $\begin{array}{l}\text { Sodium }<130 \mathrm{mmol} / 1 \\
\quad<135 \mathrm{mmol} / 1 \\
\text { Potassium }<3.5 \mathrm{mmol} / 1 \\
\text { Urea } \geqslant 7.0 \mathrm{mmol} / 1 \\
\quad \geqslant 15.0 \mathrm{mmol} / 1 \\
\text { Creatinine } \geqslant 120 \mu \mathrm{mol} / 1\end{array}$ & $\begin{array}{l}40 / 73(55) \\
59 / 73(81) \\
18 / 71(25) \\
43 / 72(60) \\
10 / 72(14) \\
20 / 42(48)\end{array}$ \\
\hline $\begin{array}{l}\text { Abnormal liver function at some time* } \\
\text { Albumin }<25 \mathrm{~g} / \mathrm{l} \text { at some time } \\
\text { Phosphate }<0.8 \mathrm{mmol} / \mathrm{l} \text { at some time }\end{array}$ & $\begin{array}{r}24 / 41(59) \\
30 / 48(63) \\
6 / 13(46)\end{array}$ \\
\hline $\begin{array}{l}\text { Proteinuria present } \\
\text { Haematuria present }\end{array}$ & $\begin{array}{l}30 / 54(56) \\
23 / 54(43)\end{array}$ \\
\hline
\end{tabular}

* Activity of two or more enzymes above the normal range.

Conversion: SI to traditional units (plasma concentrations)-Sodium, potassium: $1 \mathrm{mmol} / 1=1 \mathrm{mEq} / 1 ; \mathrm{urea}: 1 \mathrm{mmol} / 1=6.0 \mathrm{mg} / 100 \mathrm{ml}$ creatinine: $1 \mu \mathrm{mol} / 1=0.01 \mathrm{mg} / 100 \mathrm{ml}$; phosphate: $1 \mathrm{mmol} / 1=3.1 \mathrm{mg} / 100 \mathrm{ml}$ 


\section{TREATMENT AND PROGRESS}

Antibiotics had been given to 40 of 75 patients (53\%) before admission to hospital. Six had received tetracycline but none erythromycin. In hospital, antibiotics were given to all but three patients, of whom one died immediately on arrival at hospital, one had a resolving pleural effusion after a febrile illness, and one was treated for ataxia and abdominal pain, the true diagnosis of pneumonia being recognised only in retrospect. The antibiotic treatment received by one patient was not known. Most patients received from one to three antibiotics, but eight were given up to six different antibiotics. Erythromycin was given to $45(60 \%)$ of the 75 patients with known antibiotic treatment, and in $33(73 \%)$ of these cases treatment was started within 48 hours of admission. Only 10 of the 34 patients $(29 \%)$ seen before 1980 received erythromycin, compared with 35 of the $41(85 \%)$ treated thereafter. Rifampicin was given to only six patients, four of whom only received it 14 days after admission.

In 24 of the 36 patients $(67 \%)$ with detailed temperature records the temperature had settled by the fourth day, but in four a relapse associated with recrudescence of fever occurred between day 6 and day 12; one of these was already having erythromycin.

Twenty one patients $(27 \%)$ required treatment in the intensive care unit, 20 of whom had assisted ventilation because of acute respiratory failure. Assisted ventilation was started electively in all but two, who requried emergency intubation. The period of ventilation ranged from one to 39 days with a mean of 11 days. Seven of the nine deaths occurring during the course of assisted ventilation happened within seven days of admission to hospital. Six of eight patients ventilated for longer than seven days survived. The length of stay in hospital varied from one to 76 days with $65 \%$ of the 66 survivors leaving hospital by 15

Table 4 Complications of legionnaires' disease

\begin{tabular}{lll}
\hline System & Complication & $\begin{array}{l}\text { No of cases } \\
\text { (deaths) }\end{array}$ \\
\hline Renal & Renal failure requiring dialysis & $7(3)$ \\
Respiratory & $\begin{array}{l}\text { Respiratory failure* } \\
\text { Pneumothorax }\end{array}$ & $20(9)$ \\
& Pulmonary embolus & $1(1) \dagger$ \\
Cardiac & Tachyarrhythmias & $1(0)$ \\
Neurological & Unexpected cardiac arrest & $5(0)$ \\
& Epileptic fit & $3(3)$ \\
& Guillain-Barré syndrome & $1(0)$ \\
& Prolonged abnormal mental & $2(0)$ \\
Gastrointestinal & state & $1(0)$ \\
& Paralytic Ileus & $1(1)$ \\
& Haemorrhage & $1(0)$ \\
\hline
\end{tabular}

* Requiring assisted ventilation.

+One after transbronchial lung biopsy.

$\$$ Atrial fibrillation (2), atrial fiutter (1), supraventricular tachy-

cardia (1), paroxysmal atrial tachycardia (1). days and $75 \%$ by 20 days. Four patients, all of whom survived, were in hospital for more than $\mathbf{4 0}$ days.

\section{OUTCOME}

There were 13 deaths $(16 \%)$ of which four occurred in the 59 patients $(7 \%)$ who did not require assisted ventilation and nine in the $20(45 \%)$ who did $(p<0.001)$. Three patients died as a result of an unexpected cardiac arrest in a general medical ward and one was found dead in bed 28 days after admission. Of the features noted on admission, only a high plasma urea concentration $(\geqslant 15.0 \mathrm{mmol} / \mathrm{l})$ $(90 \mathrm{mg} / 100 \mathrm{ml})$ was significantly associated with risk of death $(p<0.05)$. Only $11 \%$ of the patients treated with erythromycin died compared with $23 \%$ of those who did not receive erythromycin, but this difference was not statistically significant. Fifty four per cent of deaths occurred in the first five days after admission and $77 \%$ has occurred by day 10 .

Some recorded complications are shown in table 4. No specific visible abnormalities were detected through the three bronchoscopies performed for slow resolution of radiographic consolidation, and only one of four lumbar punctures revealed abnormal cerebrospinal fluid (a raised protein concentration in the patient with Guillain-Barré syndrome).

\section{Discussion}

About 150 epidemic and sporadic cases of legionella pneumonia are reported annually in Britain. A study in 1980-1 from Nottingham found legionnaires' disease to be responsible for $15 \%$ of all community acquired cases of pneumonia seen in hospital in that year. ${ }^{5}$ In a smaller prospective investigation of consecutive cases of community acquired pneumonia in 1983 we found legionnaires' disease in only $5 \%$. These figures are similar to published data from other parts of Europe..$^{71}$ Although legionnaires' disease accounted for only $2 \%$ of all community acquired pneumonia $(3 \%$ of those in which a causal organism was identified) in a recent multicentre study in Britain, ${ }^{18}$ there appear to be regional as well as annual variations. ${ }^{619}$ The recent severe epidemic in $N$ Staffordshire has once again shown that legionnaires' $N$ disease should be considered as a potential cause of any severe pneumonia. Clinicians in Britain must 0 therefore be aware of both the typical and the atypical features of the illness.

Although other studies have found a high frequency of pre-existing chronic diseases in patients $\square$ with epidemic or nosocomial legionnaires' disease, ${ }^{120}$ 웅 we have found the typical patient to be a previously fit $\mathbb{\Phi}$ middle aged man who is a regular smoker and drinker. $\mathbb{\mathbb { D }}$ Most have been ill for one week before admission to $\stackrel{\circ}{\sigma}$ hospital. The initial suggestion of a unique clinical 
picture in legionnaires' disease ${ }^{21}$ has not been confirmed, ${ }^{40}$ but the presence of unproductive cough and in particular features suggesting multisystem disease should alert doctors to the possibility of legionnaires' disease. Indeed, the absence of respiratory symptoms in nearly a quarter of patients may mask the true diagnosis of pneumonia, especially when neurological or gastrointestinal features are prominent.

The frequently occurring hyponatraemia, lymphopenia, a high erythrocyte sedimentation rate, abnormal results in liver function tests, hypophosphataemia, hypoalbuminaemia, proteinuria, and haematuria may be pointers to the diagnosis of legionnaires' disease, but are not specific. The frequency of these features in our series is similar to that noted in other published studies. ${ }^{11420}$

The lack of a rapid and widely available diagnostic test for legionnaires' disease and the absence of a specific clinical presentation makes early diagnosis difficult. Few cases are diagnosed by culture of the organism and, as we found, only one third of those subsequently showing a fourfold rise in immunofluorescent antibody titre have titres of 16 or more at the first testing. ${ }^{22}$ Bronchial lavage and transbronchial lung biopsy may be useful for early diagnosis in selected patients. ${ }^{23}$ Simple methods for the detection of legionella antigen are under assessment ${ }^{2425}$ and may eventually be helpful for early diagnosis, but until these are widely available the initial diagnosis rests on clinical judgment. Failure to identify a pathogen from initial microbial cultures of blood and sputum may be a pointer to legionnaires' disease, especially where prior antibiotics have not been given. In a study of patients with severe community acquired pneumonia legionnaires' disease was eventually diagnosed in $52 \%$ of those in whom a pathogen had not been identified within 48 hours of admission. ${ }^{3}$ Nevertheless the occurrence of dual infections in $10 \%$ of cases indicates that isolation of another pathogen does not preclude the diagnosis.

There have been no prospective studies of antibiotic treatment in legionnaires' disease in man; but animal studies $^{2627}$ and in vitro work $^{28}$ as well as retrospective data in $\operatorname{man}^{1329}$ have supported the effectiveness of erythromycin. Our experience agrees with this. None of our patients received erythromycin before hospital admission, suggesting that its early use by general practitioners, especially during the course of an epidemic and in areas where legionnaires'.disease is known to occur, may be of advantage. As legionnaires' disease is one of the few causes of severe community acquired pneumonia in Britain we would advocate the inclusion of erythromycin in the initial antibiotic treatment of any patient with severe pneumonia. $^{3}$
Unusual features and complications of legionnaires' disease have been recorded, originating from many systems. ${ }^{30}$ The most common complication is respiratory failure. Assisted ventilation was required in a quarter of our cases. The fact that over half of these patients survived, occasionally after prolonged ventilation, emphasises the importance of this form of management for community acquired legionnaires' disease. Sudden and unexpected cardiac arrests leading to death in three patients in general medical wards confirms the need for careful monitoring of any patient suspected of having legionnaires' disease. There should be a low threshold for admission to an intensive care unit for observation and early elective assisted ventilation if required. Acute renal failure was the most common non-respiratory complication, with a similar frequency to that found in another study of sporadic legionnaires' disease. ${ }^{12}$ The pathogenesis of the widespread features of legionnaires' disease remains unexplained, but they are out of proportion to any biochemical or haemodynamic abnormalities. Bacterial dissemination, ${ }^{31}$ toxin production, ${ }^{32}$ and immunological effects ${ }^{33}$ have all been described, but it remains to be shown which is most important in producing these effects.

Unlike nosocomial legionnaires' disease, community acquired legionnaires' disease does not have a high mortality rate. Our rate is similar to the overall reported mortality of $10 \%$ for community acquired cases in Britain. ${ }^{34}$ With appropriate management the prognosis is similar to that of other forms of community acquired pneumonia seen in hospital, ${ }^{5}$ although many patients may require assisted ventilation at some stage.

We are grateful to Dr SF Pugh for access to microbiological records and to Dr AD Macrae for helpful advice in the interpretation of serological results.

\section{References}

1 Tsai TF, Finn DR, Plikaytis BD, McCauley W, Martin SM, Fraser DW. Legionnaires' disease: clinical features of an epidemic in Philadelphia. Ann Intern Med 1979;90:509-17.

2 McDade JE, Brenner DJ, Bozeman FM. Legionnaires' disease bacterium isolated in 1947. Ann Intern Med 1979;90:659-61.

3 Woodhead MA, Macfarlane JT, Rodgers FG, Laverick A, Pilkington R, Macrae AD. Aetiology and outcome of severe community-acquired pneumonia. $J$ Infect 1985;10:204-10.

$4 \mathrm{Yu}$ VL, Kroboth FJ, Shonnard J, Brown A, McDearman S, Magnussen M. Legionnaires' disease: new clinical perspective from a prospective pneumonia study. Am J Med 1982;73:357-61.

5 Macfarlane JT, Finch RG, Ward MJ, Macrae AD. Hos- 
pital study of adult community-acquired pneumonia. Lancet 1982;ii:255-8.

6 Kennedy DH, Borland W. How common is legionnaires' disease? Lancet 1983;i:360-1.

7 Mardh P-A, Myhre EB, Sandgren E. Three years experience of serodiagnosis of Legionella pneumophila infections. Acta Pathol Microbiol Immunol Scand Section B 1982;90:325-7.

8 Bouza E, Rodriguez-Creixems M. Legionnaires' disease in Spain. In: Thornsberry C, Balows A, Feeley JC, Jakubowski W, eds. Legionella. Proceedings of the second international symposium. Washington DC: American Society of Microbiology, 1984:15-7.

9 Lode H, Grothe R, Schafer H, Ruckdeschel G, Muller HE. Prospective one year study of legionnaires' disease in a German University hospital. In: Thornsberry C, Balows A, Feeley JC, Jakubowski W, eds. Legionella. Proceedings of the second international symposium. Washington DC: American Society of Microbiology, 1984:220-1.

10 Greco D, Rosmini F, Pastoris MC. Legionellosis in Italy. In: Thornsberry C, Balows A, Feeley JC, Jakubowski $\mathrm{W}$, eds. Legionella. Proceedings of the second international symposium. Washington DC: American Society of Microbiology, 1984:249-50.

11 Friis-Moller A, Rechnitzer C, Black FT, Collins MT, Aalund O. Frequency of seroreactors to Legionella species among pneumonic patients in a Danish epidemic ward. In: Thornsberry C, Balows A, Feeley JC, Jakubowski W, eds. Legionella. Proceedings of the second international symposium. Washington DC: American Society of Microbiology, 1984:258-9.

12 England AC, Fraser DW, Plikaytis BD, Tsai TF, Storch G, Broome CV. Sporadic legionellosis in the United States: the first thousand cases. Ann Intern Med 1981;94:164-70.

13 Kirby BD, Snyder KM, Meyer RD, Finegold SM. Legionnaires' disease: report of 65 nosocomially acquired cases and review of the literature. Medicine 1980;59:188-205.

14 Nordstrom K, Kallings I, Dahnsjo H, Clemens F. An outbreak of legionnaires' disease in Sweden: report of sixty-eight cases. Scand J Infect Dis 1983;15:43-55.

15 Harrison TG, Taylor AG. Diagnosis of Legionella pneumophila infection by means of formolised yolk-sac antigen. J Clin Pathol 1982;35:211-4.

16 Macfarlane JT, Miller AC, Roderick Smith WH, Morris $\mathrm{AH}$, Rose DH. Comparative radiographic features of community acquired legionnaires' disease, pneumococcal pneumonia, mycoplasma pneumonia, and psittacosis. Thorax 1984;39:28-33.

$17 \mathrm{El}$ Refaie M, Tait R, Dulake C, Dische FE. Pneumococcal antigen in pneumonia. A post mortem study with the histological and bacteriological findings. Postgrad Med J 1976;52:497-500.

18 Connolly CK, Harrison BD. Treatment of pneumonia. Br Med J 1985;290:1586.

19 White RJ, Blainey AD, Harrison KJ, Clarke SKR.
Causes of pneumonia presenting to a district general hospital. Thorax 1981;36:566-70.

20 Helms CM, Viner JP, Weisenburger DD, Chiu LC, Renner ED, Johnson W. Sporadic legionnaires' disease: clinical observations in 87 nosocomial and $\overline{\bar{\omega}}$ community-acquired cases. Am J Med Sci $\overparen{\nabla}$ 1984;288:2-12.

21 Miller AC. Early clinical differentiation between legion- के naires' disease and other sporadic pneumonias. Ann $\vec{\circ}$ Intern Med 1979;90:526-8.

22 Taylor AG, Harrison TG. Formolised yolk-sac antigen in early diagnosis of legionnaires' disease caused by Legionella pneumophila serogroup 1. Lancet 1981;ii:591-2.

23 Chiodini PL, Williams AJ, Barker J, Innes JA. Bronchial lavage and transbronchial lung biopsy in the diagnosis of legionnaires' disease. Thorax 1985;40:154-5.

24 Sathapatayavongs B, Kohler RB, Wheat LJ, et al. Rapid diagnosis of legionnaires' disease by urinary antigen detection: comparison of ELISA and radioimmunoassay. Am J Med 1982;72:576-82.

25 Bibb WF, Arnow PM, Thacker L, McKinney RM. Detection of soluble Legionella pneumophila antigens in serum and urine specimens by enzyme-linked immunosorbent assay with monoclonal and polyclonal antibodies. J Clin Microbiol 1984;20:478-82.

26 Edelstein PH, Calarco K, Yasui VK. Antimicrobial therapy of experimentally induced legionnaires' disease in guinea-pigs. Am Rev Respir Dis 1984;130:849-56.

27 Gibson DH, Fitzgeorge RB, Baskerville A. Antibiotic therapy of experimental airborne legionnaires' disease. $J$ Infect 1983;7:210-7.

28 Edelstein PH, Meyer RD. Susceptibility of Legionella pneumophila to twenty antimicrobial agents. Antimicrob Agents Chemother 1980;18:403-8.

29 Fraser DW, Tsai TR, Orenstein W, et al. Legionnaires' disease: description of an epidemic of pneumonia. $N$ Engl J Med 1977;297:1189-97.

30 Woodhead MA, Macfarlane JT. The protean manifestations of legionnaires' disease. $J \boldsymbol{R}$ Coll Physn 0 (Lond) 1985;19:224-30.

31 Weisenburger DD, Helms CM, Renner ED. Sporadic legionnaires' disease. A pathologic study of 23 fatal cases. Arch Pathol Lab Med 1981;105:130-7.

32 Baskerville A. Pathology and pathophysiology. In: 윽 Thornsberry C, Balows A, Feeley JC, Jakubowski W, D eds. Legionella. Proceedings of the second international 을 symposium. Washington DC: American Society of $\mathrm{N}$ Microbiology, 1984:136-41.

33 Friedman $\mathrm{H}$, Klein T, Widen R. Immunity to Legionella $\mathbf{N}$ pneumophila. In: Thornsberry C, Balows A, Feeley JC, స్ట Jakubowski W, eds. Legionella. Proceedings of the second international symposium. Washington DC: American Society of Microbiology, 1984:145-52.

34 PHLS Communicable Disease Surveillance Centre and $\mathbb{E}$ Office of Population Censuses and Surveys. Annual ${ }^{-}$ review of communicable diseases 1982. London: Public $\overparen{T}$ Health Laboratory Service, 1984:5. 